\title{
Editorial: Transgender health care, what you missed during your training
}

\author{
Guy T'Sjoen (iD) ${ }^{1}$ Justine Defreyne (1) ${ }^{1}$
}

Received: 4 May 2020 / Revised: 18 May 2020 / Accepted: 5 June 2020 / Published online: 14 July 2020

(c) Springer Nature Limited 2020

We feel it is an honour to present to the readers of IJIR: Your Sexual Medicine journal a special issue dedicated to transgender health care. This initiative has been taken for the first time since the existence of the journal. Indeed, such a special issue is timely seen the information available on the prevalence of gender dysphoria in society [1], and seen the available guidelines for care [2,3], some of which were published merely months ago [4]. Most experienced gender teams have seen a nearly exponential increase of referrals of people presenting with gender dysphoria over the last 10 years [5]. Explanations can be found in increasing availability of care facilities, changing legislation and a bigger visibility and acceptance of transgender individuals in media and society in general. As a consequence, a sharp increase of waiting lists to access transgender care exciding 2 years has been noted. Gender teams have not been able to keep up with the number of people applying for gender affirming care. It is clear from the changes in society and from the number of people asking for some kind of gender affirming care-be it psychological or medical-that this type of care cannot longer be reserved for specialised gender teams only. Everybody among health care workers will-sooner or later-meet at least one transgender person in their practice, and they will need to have at least basic and by preference advanced knowledge on this topic. This special issue will help you a long way, and provides even more than an introduction to transgender health care. Many of us were not educated in transgender-specific topics during our training, implying postgraduate training is much needed for formerly licensed practitioners. This is offered by EPATH, the European Professional Association for

Guy T'Sjoen

guy.tsjoen@ugent.be

1 Department of Endocrinology and Center for Sexology and Gender, Ghent University Hospital, Corneel Heymanslaan 109 K12 IE, 9000 Gent, Belgium
Transgender Health, founded in 2013, but it is also a need $I J I R$ wants to fill with this initiative.

The guest editors have collected a group of authors who are each individually leaders in the field for their specific topics. The authors represent the interdisciplinary care for transgender individuals, with contributors from social sciences, psychology and different disciplines in medicine. For those with specific interest in surgical options and care, all aspects of surgical possibilities in gender affirming surgery are discussed in full detail.

Transgender health care is a rapidly evolving scientific field. We are constantly, in collaboration with the transgender community, redefining definitions, guidelines and implementing appropriate, respectful and non-pathologizing language [6]. Other topics under debate include strict treatment schedules, required time periods for the different stages of transitioning, and age restrictions for care. The only way to solve questions is by listening to the transgender community itself, and to invest in scientific research [7].

Those opposing transgender health care-yes, they do unfortunately still exist-usually speak from their own experienced frame of reference. As scientists and licensed practitioners, we have a role to play by producing sound scientific data. Poorly informed argumentation can only be tackled with real-life data, in order to trump ill-advised opinions. For example, the ENIGI study currently has over 2400 participants, and all published data are quite reassuring towards general health outcomes [8-12]. In addition, mental health changes over gender affirming care are beneficial [13-15] and regret rates in a large cohort of participants are very low [5]. But we cannot rest; we need studies on larger numbers and with longer follow-up. Unfortunately, it is not surprising that data are still relatively limited. Most authors involved in this special issue work as clinical researchers as well as health care providers. They have the difficult but necessary task to combine excellent patient care with research activities. As transgender health care is still relatively new, many of us are still fighting for 
our place in the hospital or practice, and when we are not doing that, we are dealing with policy makers and administration. Finding research funding is also a challenge, especially difficult when in fierce competition with other areas of general medicine or psychology. Here, a break through will only be reached if specific gender-related funding opportunities will become available.

If you are completely new to this topic, we would like to welcome you to the world of transgender health care. If you are more experienced, you will find new researches and the latest review papers. Transgender people have a right to expert advice. IJIR offers you a chance at professional development. By getting involved, you are serving a transgender community, that is much larger than expected, and who have many urgent questions. Even if levels of evidence for some statements are still low, we want to reassure you based on the data already out there. Also, if you ask thousands and thousands of transgender people what they think about the need of availability of transgender-specific health care, you will learn that the need is high, the waiting lists are too long, and the appreciation for those investing their time, knowledge and career into this is tremendously high.

\section{Compliance with ethical standards}

Conflict of interest GTS is the President of EPATH, the European Professional Association for Transgender Health.

Publisher's note Springer Nature remains neutral with regard to jurisdictional claims in published maps and institutional affiliations.

\section{References}

1. Arcelus J, Bouman WP, Van Den Noortgate W, Claes L, Witcomb G, Fernandez-Aranda F. Systematic review and metaanalysis of prevalence studies in transsexualism. Eur Psychiatry. 2015;30:807-15.

2. Hembree WC, Cohen-Kettenis PT, Gooren L, Hannema SE, Meyer WJ, Murad MH, et al. Endocrine treatment of genderdysphoric/gender-incongruent persons: an Endocrine Society clinical practice guideline. J Clin Endocrinol Metab. 2017;11: 3869-903.

3. Coleman E, Bockting W, Botzer M, Cohen-Kettenis P, De Cuypere G, Feldman J, et al. Standards of Care for the health of transsexual, transgender, and gender-nonconforming people. Int $\mathrm{J}$ Transgender Health. 2012;13:165-232.

4. T'Sjoen G, Arcelus J, De Vries ALC, Fisher AD, Nieder TO, Özer $M$, et al. European Society for Sexual Medicine Position Statement "Assessment and Hormonal Management in Adolescent and Adult Trans People, With Attention for Sexual Function and Satisfaction." J Sex Med. 2020;17:570-84.

5. Wiepjes CM, Nota NM, de Blok CJM, Klaver M, de Vries ALC, Wensing-Kruger SA, et al. The Amsterdam Cohort of Gender Dysphoria Study (1972-2015): trends in prevalence, treatment, and regrets. J Sex Med. 2018;15:582-90.

6. Bouman WP, Schwend AS, Motmans J, Smiley A, Safer JD, Deutsch MB, et al. Language and trans health. Int $\mathrm{J}$ Transgender Health. 2017;18:1-6.

7. Adams N, Pearce R, Veale J, Radix A, Castro D, Sarkar A, et al. Guidance and ethical considerations for Undertaking Transgender Health Research and Institutional Review Boards Adjudicating this Research. Transgender Health. 2017;2:165-75.

8. Wierckx K, Van Caenegem E, Schreiner T, Haraldsen I, Fisher A, Toye K, et al. Cross-sex hormone therapy in trans persons is safe and effective at short-time follow-up: results from the European network for the investigation of gender incongruence. J Sex Med. 2014;11:1999-2011.

9. van Dijk D, Dekker MJHJ, Conemans EB, Wiepjes CM, de Goeij EGM, Overbeek KA, et al. Explorative prospective evaluation of short-term subjective effects of hormonal treatment in trans people -results from the European Network for the Investigation of Gender Incongruence. J Sex Med. 2019;16:1297-309.

10. Defreyne J, Vantomme B, Van Caenegem E, Wierckx K, De Blok CJM, Klaver M, et al. Prospective evaluation of hematocrit in gender-affirming hormone treatment: results from European Network for the Investigation of Gender Incongruence. Andrology. 2018;6:446-54.

11. Wiepjes CM, Vlot MC, Klaver M, Nota NM, de Blok CJM, de Jongh RT, et al. Bone mineral density increases in trans persons after 1 year of hormonal treatment: a multicenter prospective observational study. J Bone Miner Res. 2017;32:1252-60.

12. Van Velzen DM, Paldino A, Klaver M, Nota NM, Defreyne J, Kees Hovingh G, et al. Cardiometabolic effects of testosterone in transmen and estrogen plus cyproterone acetate in transwomen. $\mathrm{J}$ Clin Endocrinol Metab. 2019;104:1937-47.

13. Heylens G, Verroken C, De Cock S, T'Sjoen G, De Cuypere G. Effects of different steps in gender reassignment therapy on psychopathology: a prospective study of persons with a gender identity disorder. J Sex Med. 2014;11:119-26.

14. Fisher AD, Castellini G, Ristori J, Casale H, Cassioli E, Sensi C, et al. Cross-sex hormone treatment and psychobiological changes in transsexual persons: two-year follow-up data. J Clin Endocrinol Metab. 2016;101:4260-9.

15. van de Grift TC, Elaut E, Cerwenka SC, Cohen-Kettenis PT, De Cuypere G, Richter-Appelt H, et al. Effects of medical interventions on gender dysphoria and body image: a follow-up study. Psychosom Med. 2017;79:815. 